American Journal of Environmental Sciences 6 (6): 516-522, 2010

ISSN 1553-345X

(C) 2010 Science Publications

\title{
A Monitoring System for Mitigation Planning: The Case of "Bagnaschino" Landslide in Northern Italy
}

\author{
Giuliani Andrea, Bonetto Sabrina, Castagna Sara, Comina Cesare and Mandrone Giuseppe \\ Department of Earth Science, University di Torino, \\ Via Valperga Caluso, 35-10125 Torino Italy
}

\begin{abstract}
Problem statement: The Bagnaschino landslide occurred in November 1994 that caused extensive floods and many landslides all over northern Italy. In southern Piedmont, the Casotto River (Cuneo Province) damaged many kilometers of provincial road and the river was dammed by this landslide. The landslide involves an area of about 100 thousands $\mathrm{m}^{3}$, but a good knowledge of the landslide is however still missing because of the complexity of the phenomenon. Approach: The aim of this study has been to collect and reorganize available data with the georeferencing in a GIS project of the information taken from investigations of the last years. An electric tomography and seismic reflection were carried out above the landslide body to enrich the available data. The final goal has been to well-know the sliding surfaces and the different processes involved in the slope deformation. Results: The research has redefined the geological base model, that was been the local stratigraphy is represented by an heterogeneous deposit of loose materials $(20-30 \mathrm{~m})$, with abundant silty-clayey matrix. The bedrock is composed by fractured micashists, metabolites and green stones. The landslide has shown many surfaces of movement at different depths and continuous reactivations, but the triggering mechanism is still not clarified due to the complex geological setting. Conclusion: Rock masses observed in correspondence of the road and the river bed has suggested that the main sliding surface did not involve the lower part of the slope and that the road is built on stable bedrock. The intention will be to continue the monitoring of the landslide in order to give to the Local Authorities the correct instruments for planning mitigation projects.
\end{abstract}

Key word: Complex slope instability, subsoil investigations, topographic survey, monitoring systems

\section{INTRODUCTION}

The Bagnaschino landslide is located in southern Piedmont Alps (Cuneo, NW Italy) along the west side of the Casotto Valley. The landslide occurred between 550 and $650 \mathrm{~m}$ a.s.l. with a length of $300 \mathrm{~m}$ and a width of $250 \mathrm{~m}$. The falling down materials dammed the river and destroyed the road (S.P. $\left.\mathrm{n}^{\circ} 164\right)$ placed in the lower part of the slope during the heavy rainfall of autumn 1994 (Fig. 1).

In 1997 mitigation works were planned consisting in debris removing, regularization and profiling of the landslide area, use of biotechnical stabilization techniques, surface drains, diversion ditches and horizontal gravity drains. Finally, a rock shed anchored to stable rock was built to protect the road. In 2004, new morphological evidences such as subsidences, trenches and scarps were observed around the landslide body, while previous stabilisation works and monitoring systems were seriously damaged, except artificial tunnel (Fig. 2).
Local Authorities are particularly concerned with the phenomenon because of the presence of the only road to the upper part of the valley and the progressive reactivations of the landslide (still active nowadays). Both surface observations and subsurface explorations were financed, but-up to now-the triggering mechanism and also the type of kinematics are still unclear. Cooperation between Geological Bureau of the Province of Cuneo and the Earth Science Department of the University of Torino started in 2009 with the aim to increase the knowledge of the phenomenon. In fact, the inventory and critical examination of all existing data, combined with a detailed and updated geologicgeomorphologic field surveying were still lacking before this study (Ahmad et al., 2006). Moreover, two deep drillings were executed and samples were collected for laboratory tests.

Geological and morphological setting: The rock masses outcropping in the landslide area belong to the

Corresponding Author: Giuliani Andrea, Department of Earth Science, Università degli Studi di Torino, Via Valperga Caluso, 35 10125 Torino (TO) Italy Tel: +390116705139 Fax: +390116705182 


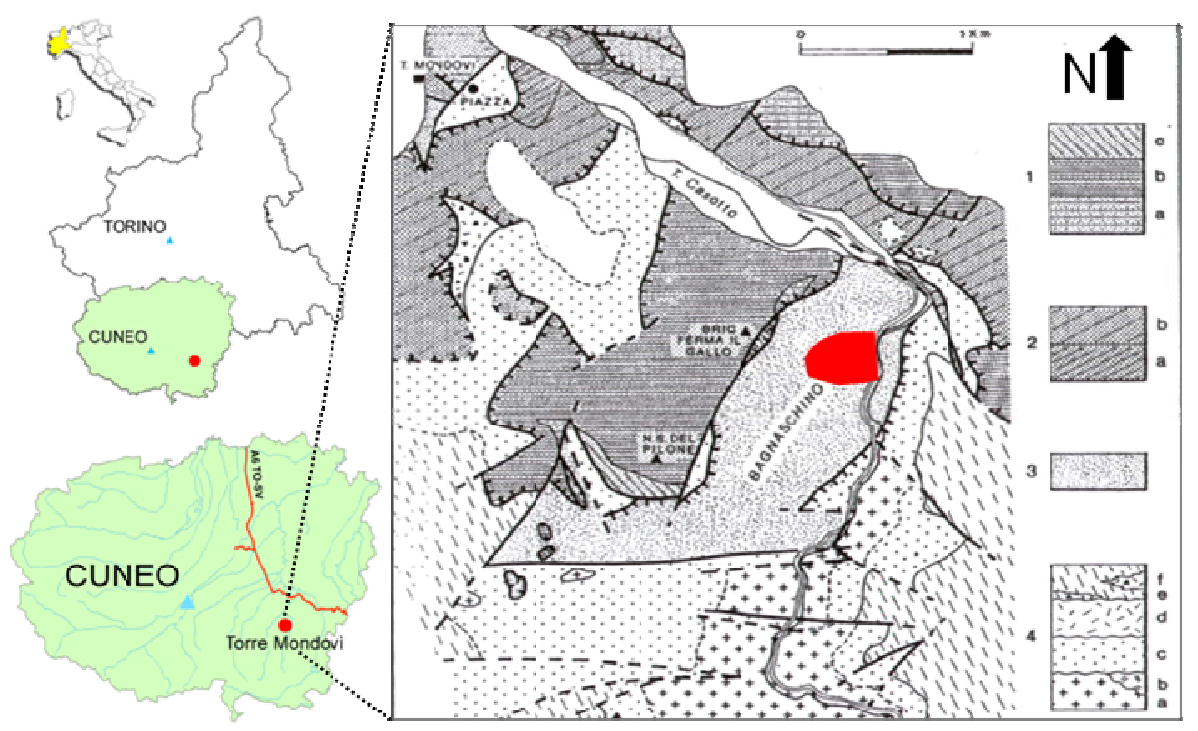

Fig. 1: Geographical and geological setting of the study area (modified after (Dallagiovanna, 1994)). piedmont units -1.Villanova Unit: (a) quarzitic porphyries (Permo-Trias), (b) dolostones (Trias), (c) limestone (Trias); (2) Montaldo Unit: (a) breccia, (b) calcschists; BRIANZONESE UNITS-(3) Bagnaschino Unit; (4) Pamparato Murialdo Unit: (a) Ortogneiss, (b) Granofirs, (c) Lisio Formation, (d) meta rhyolite, (e) schists, (f) andesites. White colour: Oligo-miocenic and Quaternary deposits
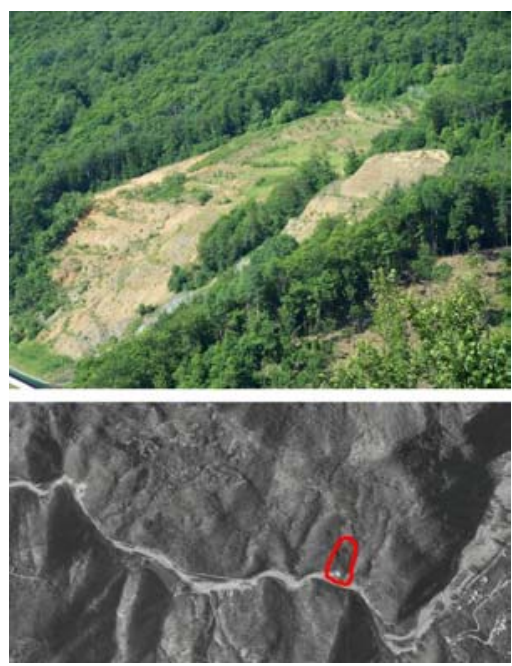

Fig. 2: Overview of the left side of Casotto Valley affected by the landslide, as indicated in the aerial photo

Bagnaschino Unit, part of the Brianzonese Domain in the Western Alps (Vanossi et al., 1994). It is an east dipping monoclinal mainly formed by amphibolites associated to paragneiss and micaschist with green stone inclusions (Dallagiovanna, 1994).

The geological and geomorphological surveys show gradient variations and morphological evidences such as subsidences, trenches and scarps are widespread also in the surrounding area (Fig. 3). Geomorphologic features seem to highlight a policycling situation, characterized by two different morphogenic actions, periglacial at the top (with gentle dipping) and fluvial at the bottom (Mandrone et al., 2007). In fact, Late and Post-glacial entrenchment of the hydrographical network forms a steep V-shaped valley and generates poor alluvial deposits and very few traces of alluvial terraces. The landslide affect the $\mathrm{W}$ side of main valley, causing the deviation of the Casotto River.

\section{MATERIALS AND METHODS}

Investigations: An engineering geological survey was carried out for two years within the landslide area, following some previous experiences (Mandrone, 2006; Mandrone et al., 2009). Drillings and field instrumentations were installed since 1997 for surface and subsurface measurements (Table 1 and Fig. 3). Several inclinometers and piezometers were placed in the landslide area; however most of them have been immediately broken due to the movements and are nowadays not working. In particular, in 2008 an unconventional inclinometer was installed: it was a Multiparametric System (DMS) with automatic detection and real-time data transmission that allowed continuous measurements (Hong et al., 2005). 


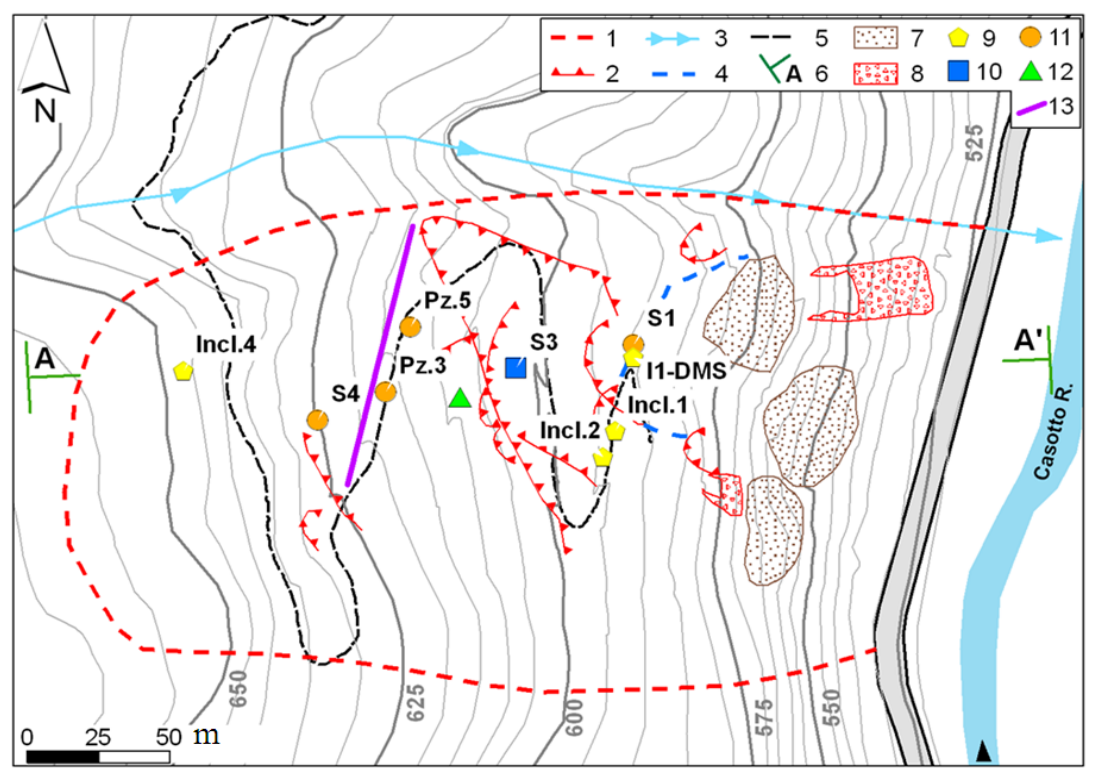

Fig. 3: Geomorphologic map and subsurface investigations location. Keys: (1) landslide limit; (2) scarp; (3) water outflow; (4) cracking; (5) new track; (6) section trace; (7) sliding deposits; (8) rock-fall deposit; (9) inclinometers; (10) drilling; (11) piezometers (12) weather station; (13) electric tomography

\begin{tabular}{|c|c|}
\hline Year & Number and type \\
\hline 1997 & $\begin{array}{l}5 \text { drillings in the landslide area }(30 \mathrm{~m} \text { of depth each), } \\
2 \text { inclinometers }(30 \mathrm{~m} \text { of depth each }), 1 \text { piezometer }\end{array}$ \\
\hline 2000 & $\begin{array}{l}2 \text { drillings ( } 35 \text { and } 70 \mathrm{~m} \text { of depth each ), } \\
2 \text { inclinometers, } 2 \text { piezometers }\end{array}$ \\
\hline 2006 & 1 drilling ( $50 \mathrm{~m}$ of depth), 1 inclinometer \\
\hline 2008 & $\begin{array}{l}3 \text { drilling (respectively } 60,70 \text { and } 100 \mathrm{~m} \text { depth) } \\
\text { with piezometer and inclinometer ( } 70 \mathrm{~m} \text { depth) }\end{array}$ \\
\hline
\end{tabular}

The early drillings (1997), relatively superficial. investigated only the outer part of the displaced material, without reaching the underlying sliding surface. Recently, two more deep drillings were carried out: one $(60 \mathrm{~m}$ deep) is located in the upper part of the slope and it is equipped with a piezometer screened from $51-60 \mathrm{~m}$; the other $(100 \mathrm{~m}$ deep) is placed in the upper part of the landslide and is equipped with a piezometer screened from $60-78 \mathrm{~m}$.

Civil Protection of Piedmont Region carried out a topographic monitoring from Oct. 2006-Nov. 2008 using twelve benchmarks and a mechanized theodolite installed in a cabin placed on the opposite side of the valley. At the same time, from 2006-2009, another experimental system (SEPA) was installed, based on a radar technique using three benchmarks and two fixed stations.

Hydro-meteorological studies were carried out in continuous comparing data from six weather stations but only is within the landslide area. All of them confirm a subalpine pluviometric regime with a minimum in the winter and maximum in autumn (main) and spring (secondary) and an annual rainfall ranging from 1.000-1.200 mm (Fig. 4).

Geophysical surveys: Two main indirect explorations of the landslide were done in 1997 an 2009 with geophysical techniques, also based on previous experiences (Comina et al., 2008). In 1997, investigations consisted in electric tomographies (both from the surface than in boreholes), vertical electrical soundings, seismic refraction profiles and magnetic surveys executed on the landslide body; the later one (2009) consists in electric tomography and seismic reflection carried out above the landslide body (Godio et al., 2006).

Most of the earlier geophysical surveys were shallow investigation (about $30 \mathrm{~m}$ ) and they just revealed the high variability of the mechanical and electric properties of the loose deposits inside the landslide. These data have moreover underlined the quite low resistivity of the shallower deposits indicating a relevant water content that is the principal reason for landslide movements (Fig. 5).

On the contrary, more recent surveys allowed a deeper investigation delineating the high level of alteration and fracturation of the bedrock. However these last explorations were not located directly on the sliding body so that further analysis will be necessary to relate the evidences of these surveys to the landslide. Again, the lack of coordination in surveys planning has brought to a unclear framework for the landslide. 


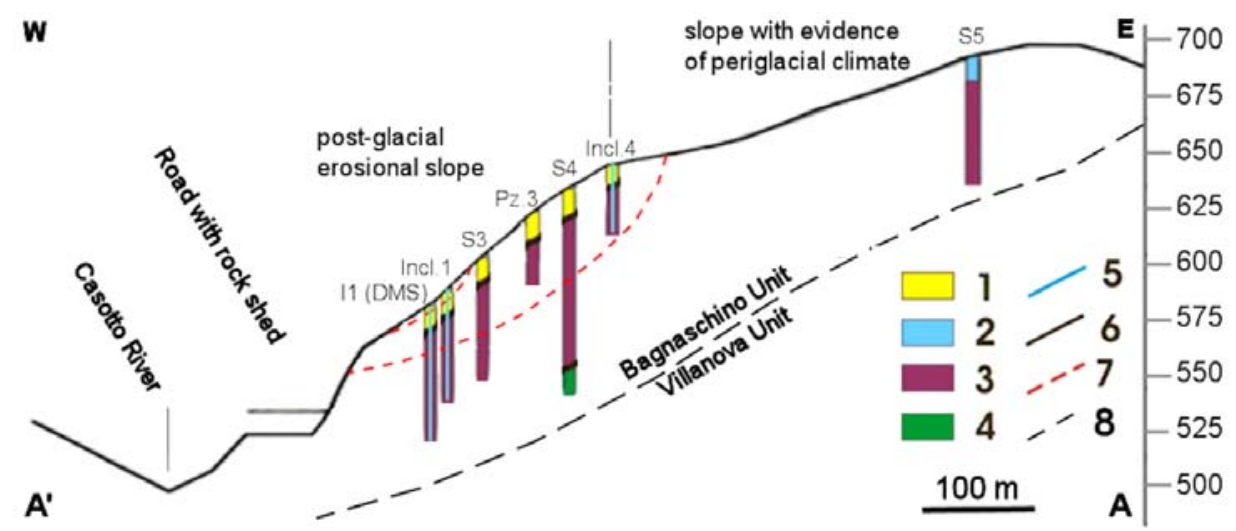

Fig. 4: Longitudinal section of landslide (the height scale bar is twice that of the length ones). Keys: (1) heterometric deposits (gravel and pebbles in fine-grained matrix), (2) silty deposits, (3) heavily broken/weathered / disturbed rock masses, (4) bedrock, (5) inclinometer, (6) lithologic limits, (7) surface of movement, (8) tectonic contact

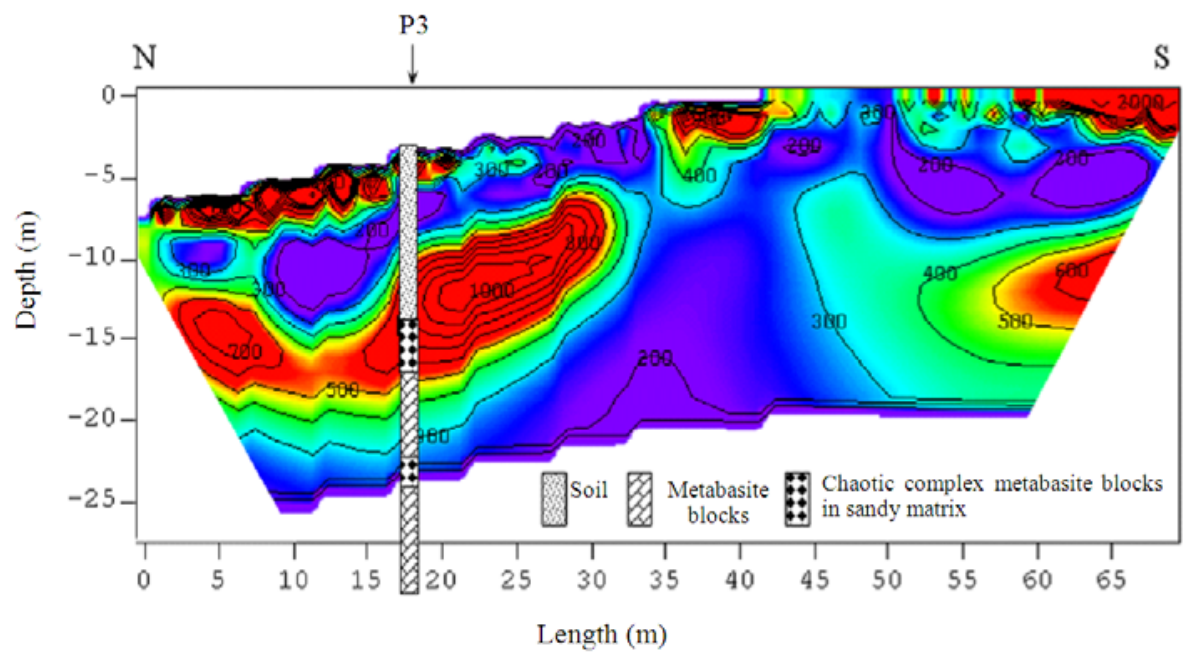

Fig. 5: Electric tomography of the upper part of the landslide body; for location Fig. 2 (modified after Godio et al., 2006, personal communication)

\section{RESULTS}

The geological model of the landslide: a global change in the grain size distribution of the covers is generally observed pointing out the presence of mainly uniform-fine material (silty sand) at the top of the slope and heterometric deposits (gravely-silty sand with pebbles) in the main landslide body. In particular, the explorations highlight the presence in the landslide body of thick covers (up to $30 \mathrm{~m}$ thick) mainly constituted by loose and heterometric material with abundant finegrained content (up to 30\%) followed by heavily weathered and disturbed micaschists progressively passing to heavily broken micaschists with mixture of angular and rounded serpentinitic fragments. In deeper drillings, amphibolite has been also intercepted. Water was found at different depths, usually in the most shallow layers and mainly due to changes in the permeability of deposits.

As a further evidence of the enduring slope movements (particularly during 2004-2006 and 2009), several field instruments installed on the landslide body (inclinometers and piezometers) were involved in the deformations and most of them became useless. For example, in 2006, two months after its installation, an inclinometer showed two different dislocations at 45 and at $17 \mathrm{~m}$ depth, while in 2009 the DMS system revealed a movement at $7 \mathrm{~m}$ depth exceeding the maximum total deformation of the instrument $(59 \mathrm{~cm})$. 


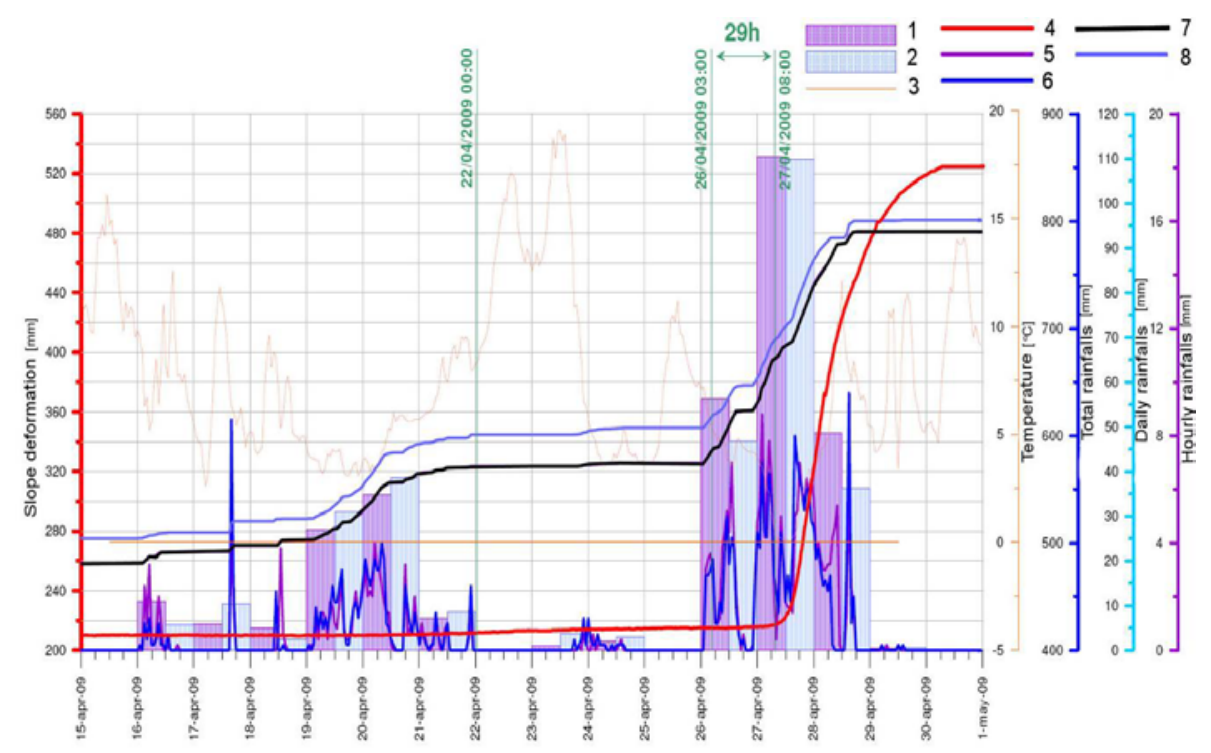

Fig. 6: Example of correlation between rainfall events and landslide movements recorded by the DMS in April 2009. Keys: 1) daily rainfalls at Viola station, 2) daily rainfalls at Pamparato station, 3) temperature at Viola, 4) slope deformations documented by DMS measures , 5) hourly rainfalls at Viola, 6) hourly rainfalls at Pamparato, 7) total rainfalls at Viola, 8) total rainfalls at Pamparato.

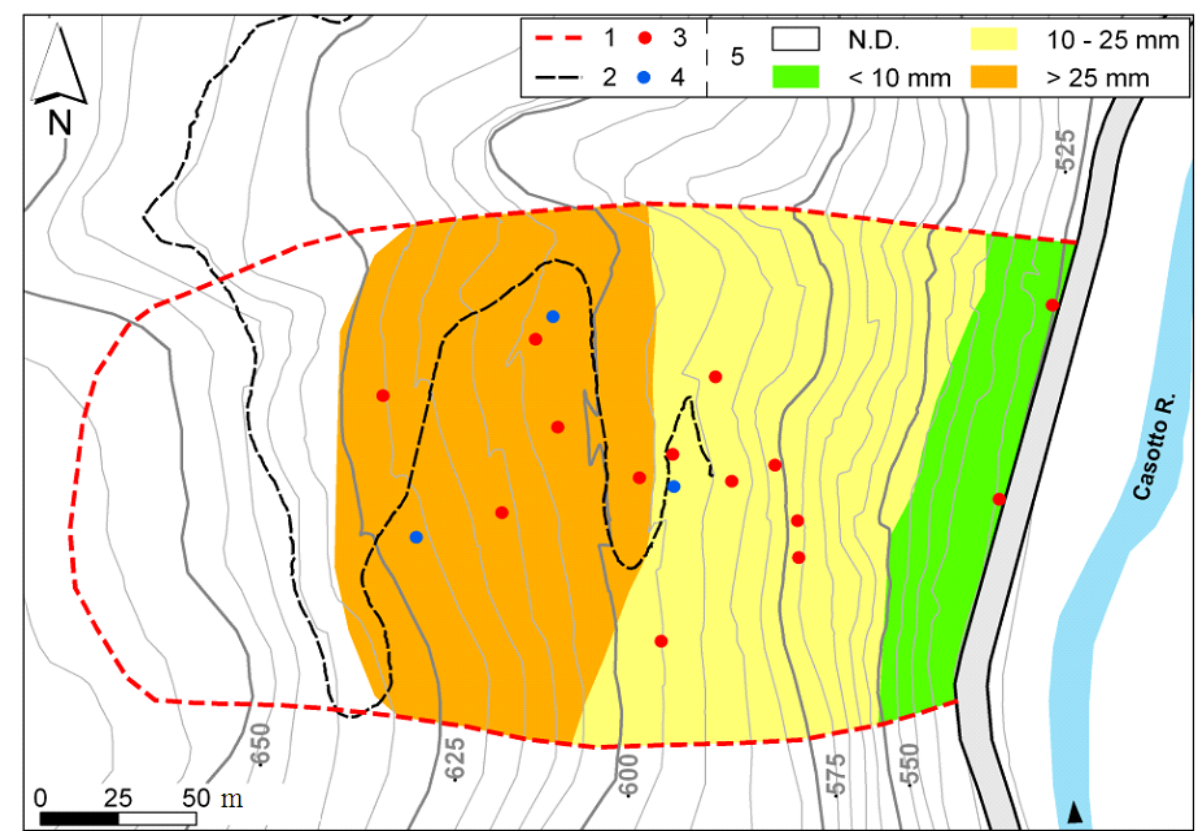

Fig. 7: Areas with different rate of displacement. Keys: (1) landslide limit, (2) new track, (3) topographic benchmarks, (4) SEPA topographic benchmarks, (5) displacement classes between October-2007 and May 2008 (N.D. = No Data available)

According to meteorological data, it has been however observed that the main movements recorded by DMS are well correlated with rainfall events (Fig. 6).
Despite local and periodic deformations (some millimeters) recorded by topographical surveying, both technical and technological problems resulted in 
numerous and extensive gaps in the time series of data and correlation with rainfalls became difficult too (Huat et al., 2005). However areas with different rate of displacement have been recognized (Fig. 7): particularly the upper part of the landslide seems to be the more critical one.

\section{DISCUSSION}

The main questions related to this landslide concern number, shape and position of the sliding surfaces and moreover, identification of the different processes involved in the slope deformation.

The Late Glacial and Holocene intense stream erosion produced steep slopes and pressure-release of the rock mass, favoring the weathering processes and reducing the shear strength of fractured rock mass. The weathering in association with the strong tectonic deformation produced in the rock mass a widespread dissolution of the carbonate compounds and a substantial weakening of the Villanova Unit.

In the central part of the slope, where swelling clays are abundant, rock creep takes place. The slow movement affects resistant beds lying on degradable layers producing the bending of stronger layers in a downhill direction and dismembers the fractured beds forming arrays of cracks-bounded blocks up to ten meters in length (Clerici et al., 2002). Due to the disturbance of the bedrock, sometimes it's difficult to discriminate between quaternary deposits and material coming from micaschists frustration and weathering.

\section{CONCLUSION}

The study has focused on the collection and critical processing of data collected during the last 15 years about a complex landslide (Cruden and Varnes, 1996) characterized by many reactivations, involving bedrock and thick loose deposits along a slope in the southern piedmont Alps (Varnes, 1978).

According to the surveying results, the landslide seems to show many surfaces of movement at different depths and continuous reactivations. In spite of substantial financing in explorations and monitoring, the triggering mechanism and the phenomenon velocity are still not clarified due to the complex geological setting. Moreover, the damage of the most part of monitoring instruments produces the inconsistency of some results.

Due to the limited number and the bad conditions of outcrops, it is sometime difficult to establish if outcrops represent bedrock or dislocated blocks. Nevertheless, rock masses observed in correspondence of the road and the river bed suggest that the main sliding surface does not involve the lower part of the slope and that the road is built on stable bedrock and it is only indirectly influenced by the run out of the displaced material.

Geological and conceptual model of the slope should be increased with a proper location of investigation and monitoring system suited to the complexity of the movement, with particular regard to the continuity of the measurement and the depth of investigations.

\section{REFERENCES}

Ahmad, F., A.S. Yahaya and M.A. Farooqi, 2006. Characterization and geotechnical properties of Penang residual soils with emphasis on landslides. Am. J. Environ. Sci., 2: 121-128. DOI: 10.3844/ajessp.2006.121.128

Clerici, A., G. Mandrone, C. Tellini and P. Vescovi, 2002. The Geomorphological and Kinematic Evolution of the Anzola Landslide (Northern Apennines, Italy). In: Landslides. Rybar, J., J. Stemberk and P. Wagner, (Eds.). Rotterdam, ISBN: 90-5809-393X, pp: 143-160.

Comina, C., C. Festa, S. Foti and G. Musso, 2008. Monitoring 3D diffusion processes with high-speed electric tomography. Lead. Edge, 27: 468-471. DOI: 10.1190/1.2907177

Cruden, D.M. and D.J. Varnes, 1996. Landslide Types and Processes. In: Landslides Investigation and Mitigation, Special Report 247. Turner A.K. and R.L. Schuster (Eds.). Transportation Research Board, National Research Council, Washington, ISBN: 0309061512, pp: 36-75.

Dallagiovanna, G., 1994. Rilevamento geologico e analisi strutturale della zona compresa fra le valli mongia e corsaglia (Alpi Liguri). Atti Tic. Sci. Terra, 37: 133-154.

Godio, A., C. Strobbia and G. De Bacco, 2006. Geophysical characterization of a rockslide in an alpine region. Eng. Geolo., 83: 273-286. DOI: 10.1016/j.enggeo.2005.06.034

Hong, Y., H. Hiura, K. Shino, K. Sassa and H. Fukuoka, 2005. Quantitative assessment on the influence of heavy rainfall on the crystalline schist landslide by monitoring system-case study on zentoku landslide, Japan. Landslides, 2: 31-41. DOI: 10.1007/s10346-005-0044-6

Huat, B.B.K., F.H. Ali and S. Mariappan, 2005. A study on suction-rainfall response of a cut slope in unsaturated residual soil using a field rain simulator. Am. J. Environ. Sci., 1: 11-15. DOI: 10.3844/ajessp.2005.11.15 
Mandrone, G., 2006. Engineering geological mapping of heterogeneous rock masses in the northern Apennines: an example from the Parma Valley (Italy). Bull. Eng. Geol. Environ., 65: 245-252. DOI: 10.1007/s10064-006-0039-0

Mandrone, G., A. Clerici and C. Tellini, 2007. Evolution of a landslide creating a temporary lake: successful prediction. Quat. Int., 171-172: 72-79. DOI: 10.1016/j.quaint.2006.10.006

Mandrone, G., L. Buratti, A. Chelli, L. Lopardo and C. Tellini, 2009. A huge, slow moving earth flow in the northern Apennines: The Signatico landslide (Italy). Geogr. Fis. Dinam. Quat., 32: 247-253.
Vanossi, M., C.R. Perotti and S. Seno, 1994. The maritime alps arc in the ligurian and tyrrhenian systems. Tectonophysics, 230: 75-89. DOI: 10.1016/0040-1951(94)90147-3

Varnes, D.J., 1978. Slope Movement Types and Processes. In: Landslides, Analysis and Control, Schuster R.L. and R.J. Krizek (Eds.). National Academy of Sciences, Washington, pp: 11-33. 